\title{
KLASIFIKASI OBJEK BERDASARKAN WARNA, BENTUK DAN DIMENSI
}

\author{
Budi Sugandi ${ }^{1)}$, Aprianto, Riwan Doni ${ }^{2)}$, dan Dwi Ayu Imardiyanti ${ }^{3)}$ \\ 1,2,3 Jurusan Teknik Elektro, Politeknik Negeri Batam, Jl. Ahmad Yani, Batam, 29461 \\ E-mail: 1 budi_sugandi@polibatam.ac.id
}

\begin{abstract}
This research aimed to develop an algorithm to classify an object based on color, shape and dimension. In this research, the classification process was designed on two combined features which are color-shape, color-dimension, and shape-dimension. Each two combined features yielded 9 classification results. Therefore, in total, the number of classifications of three combined features were 27 classifications. The algorithm was depeloved as follows. The color feature was classiffied using RGB color histogram. Each object histogram was compared and calculated the distance to the reference object histogram. The similarity was determined with the smaller distance to the reference object. The shape feature was classified using shape matching algorihtm. The algorithm measured the similarity based on distance between two point on each geometry. The dimension feature was classified using the number of the pixel on each object. The number of pixel was callibrated on certain distance to the camera. The algoritma was also designed to classify the reject object (Not Good/NG). The algortihm was implemented on a conveyor system as a sorting machine. The conveyor has 10 output classification, 9 output for object classification and 1 output for NG object. The experimental results showed the sistem could classify the object in 27 category classification and 1 NG category.
\end{abstract}

Keywords: object cleassification, object feature, RGB color histogram, shape matching, object sorting

\begin{abstract}
ABSTRAK
Penelitian ini bertujuan untuk membangun algoritma untuk pengklasifikasian objek berdasarkan warna, bentuk dan dimensi. Dalam penelitian ini, pengklasifikasian didesain dalam dua ciri gabungan yaitu warna-bentuk, warna-dimensi dan bentuk-dimensi. Tiap-tiap dua ciri gabungan tersebut akan menghasilkan 9 hasil klasifikasi. Sehingga total klasifikasi gabungan 3 ciri adalah 27 klasifikasi. Algoritma yang dikembangkan untuk masing-masing ciri adalah sebagai berikut. Ciri warna diklasifikasikan menggunakan histogram warna RGB. Tiap objek dibandingkan histogramnya dan dihitung jarak tiap histogram dengan histogram referensi. Semakin dekat dengan histogram referensi, maka objek tersebut diklasifikasikan sama dengan objek referensi. Ciri bentuk diklasifikasikan menggunakan algoritma shape matching. Algoritma shape matching mengukur kemiripan objek berdasarkan jarak antar titik dalam objek geometri. Semakin rendah perbedaannya menunjukkan semakin mirip objek tersebut. Sementara ciri dimensi diklasifikasikan menggunakan perhitungan jumlah pixel pada tiap objek. Jumlah pixel dikalibrasi pada jarak tertentu dari pengkapturan objek oleh kamera. Selain itu, algoritma ini pun didesain untuk dapat mengklasifikasi objek yang tidak masuk kategori dan diklasifikasikan sebagai objek yang rusak (Not Good/NG). Algoritma ini selanjutnya diimplemenasikan dalam sebuah konveyor sebagai mesih pemisah objek yang mempunyai 10 keluaran. Sembilan keluaran untuk objek hasil klasifikasi dan satu keluaran untuk objek dalam kategori NG. Hasil eksperimen menunjukkan sistem dapat mengklasifikasi objek dalam 27 kategori dan 1 kategori NG.
\end{abstract}

Kata Kunci: klasifikasi objek, ciri objek, histogram warna RGB, shape mathing, pemilah objek 


\section{PENDAHULUAN}

Dengan terus berkembangnya teknologi, hampir semua proses yang dilakukan di industri beralih dari proses yang konvensional ke proses otomasi. Proses otomasi digunakan untuk memudahkan dan mempercepat proses yang dilakukan sehingga menghasilkan produk yang lebih baik dengan keakuratan yang tinggi. Untuk mendukung hal itu, maka kita dituntut untuk selalu mengembangkan teknologi baik dari segi perangkat keras maupun perangkat lunak. Salah satu bentuk teknologi yang berkembang saat ini adalah proses otomasi untuk memilah barang berdasarkan beberapa kriteria khusus yang ditetapkan oleh pengguna seperti warna, bentuk dan dimensi dari objek tersebut.

Beberapa penelitan telah dikembangkan untuk mengklasifikasi objek berdasarkan kriteria warna, bentuk dan dimensi dan telah diimplementasikan dalam beberapa perangkat yang berbeda. Priya (2017) mengembangkan sistem penyortiran objek menggunakan robot berdasarkan bentuk objeknya. Penelitiannya telah berhasil memisahkan objek dalam 5 bentuk seperti bujur sangkar, persegi panjang, lingkaran, segienam, dan segitiga. Sagita dan Rozany (2017) melakukan penyortiran objek berdasarkan warna yang diimplementasikan dalam perangkat Programmable Logic Controller (PLC). Mereka berhasil mengklasifikasikan objek dalam tiga warna yaitu merah, hijau dan biru. Sementara Pangestu dkk. (2016) mengimplementasikannya dalam sebuah lengan robot. Mereka berhasil menyortir objek berdasarkan warna merah, kuning dan biru dengan tingkat keberhasilan sekitar 76\%. Arbye dkk. (2014) mengembangkan pengendalian pemisah objek berdasarkan warna untuk menyortir 5 buah warna yaitu merah, hijau, biru, hitam dan putih. Mereka memperoleh tingkat keberhasilan sebesar 84\%. Kondhare dkk (2014) mengembangkan sistem penyortiran objek berdasarkan gabungan dua kriteria yaitu bentuk dan warna objeknya. Mereka berhasil menyortir objek berupa lingkaran dan persegi panjang dalam tiga warna yaitu merah, hijau dan biru. Hutabarat dkk. (2013) menggunakan gabungan ciri yang sama yaitu bentuk dan warna dan diimplementasikan dalam bentuk konveyor untuk menyortir barang. Dari hasil penelitian mereka diperoleh galat rata-rata sebesar $10 \%$ pada bentuk lingkaran dengan warna hijau, merah dan kuning.

Metode yang digunakan untuk pemisahan barang menggunakan ciri warna, bentuk dan dimensi telah dikembangkan oleh banyak peneliti. Hani \& Mustafah (2013) lebih memilih menggunakan warna HSV untuk mendeteksi objek. Kim \& Jeoung menggunakan warna RGB untuk mendeteksi suatu objek. Rahman dkk. (2014) mengusulkan penggunaan HSV dan YCbCr untuk mendeteksi objek. Sementara untuk pendeteksian objek berdasarkan bentuk telah dipresentasikan oleh (Chetan \& Atish, 2016) dan (Toshev \& Taskar, 2012). Mereka mensegmentasi objek berdasarkan tepian objek untuk dibandingkan dengan template objek. Penelitian untuk memperkirakan dimensi objek dari citra yang terkapture kamera telah banyak dilakukan. Mane \& Yangandul (2016) melakukan pengukuran dimensi objek dengan memproyeksikan garis vertical pada jarak $5 \mathrm{~cm}$ dari kamera ke masing-masing garis horizontal. Dengan menggunakan interpolasi, didapatkan dimensi masingmasing objek. Chiryshev dkk. (2017) mencoba mendeteksi dan menghitung dimensi objek menggunakan model rekontruksi. Mereka berhasil mendeteksi dimensi objek dengan rate $96.9 \%$.

Dari beberapa referensi yang tersedia, pengembangan pemisah barang dengan spesifikasi dapat memisahkan barang dalam tiga ciri warna, bentuk dan dimensi sangatlah terbatas atau bahkan belum ada. Selain itu, keakuratan pemisahan barang 
masih sangat rendah dan perlu untuk ditingkatkan kembali. Untuk menanggulangi permasalahan di atas, dalam artikel ini dikembangkan suatu mesin pemisah barang yang dapat memisahkan barang berdasarkan 3 ciri yaitu warna, bentuk dan dimensi. Pengklasifikasian didesain dalam dua ciri gabungan yaitu warna-bentuk, warnadimensi dan bentuk-dimensi. Tiap-tiap dua ciri gabungan tersebut akan menghasilkan 9 hasil klasifikasi. Sehingga total klasifikasi gabungan 3 ciri adalah 27 klasifikasi ditambah satu kategori untuk barang yang tidak masuk kriteria (NG).

\section{METODE PENELITIAN}

Dalam penelitian ini, pengklasifikasian didesain dalam dua ciri gabungan yaitu warna-bentuk, warna-dimensi dan bentuk-dimensi. Algoritma yang dikembangkan untuk masing-masing ciri adalah sebagai berikut. Ciri warna diklasifikasikan menggunakan filter warna RGB dan histogram warna RGB. Ciri bentuk diklasifikasikan menggunakan algoritma shape matching (Chitra dkk, 2009). Algoritma shape matching mengukur kemiripan objek berdasarkan jarak antar titik dalam objek geometri. Sementara ciri dimensi diklasifikasikan menggunakan perhitungan jumlah pixel pada tiap objek. Jumlah pixel dikalibrasi pada jarak tertentu dari pengkapturan objek oleh kamera. Secara umum algoritma pengklasifikasian objek digambarkan dalam Gambar 1.

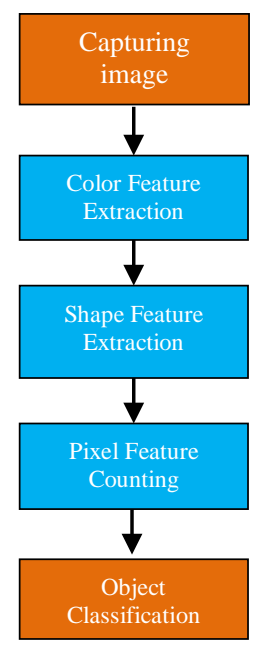

Gambar 1. Diagram alur proses keseluruhan sistem klasifikasi

Proses pertama yang dilakukan pada memfilter satu warna yang sesuai dan sistem klasfikasi ini adalah pengkapturan citra oleh kamera. Proses pengkapturan dilakukan pada conveyor yang digerakan oleh sebuah motor. Proses pengkapturan terjadi pada saat objek terdeteksi oleh sensor proximity sehingga menghentikan pergerakan motor dan objek diam. Objek yang terkapture diproses dalam PC untuk diklasifikasikan berdasarkan tiga ciri yaitu warna, bentuk dan dimensi.

Ekstraksi warna dilakukan dalam dua tahap yaitu dengan filter warna RGB dan histogram RGB. Filter warna RGB akan akan menghilangkan warna yang tidak diinginkan. Objek dengan warna yang telah difilter kemudian dihitung histogramya untuk mendapatkan range warna masing-masing objek. Dalam artikel ini, kami menggunakan histogram RGB untuk pengklasifikasian objek berdasarkan warna. Histogram dihitung untuk tiap objek yang akan diklasifikasi sehingga didapatkan threshold warna RGB pada tiap objek seperti yang ditunjukkan oleh gambar 2. 


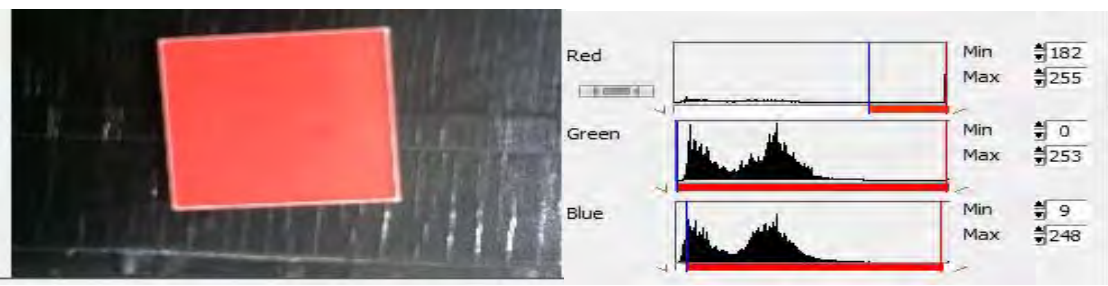

a. Threshold warna merah



b. Threshold warna hijau

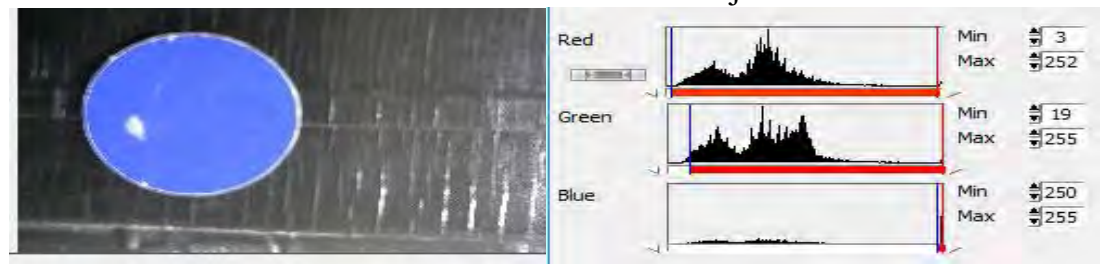

c. Threshold warna biru

Gambar 2. Threshold warna objek berdasarkan histogram RGB

Dari Gambar 2 didapatkan threshold untuk masing-masing warna objek adalah Merah $(\mathrm{R}=182-255, \mathrm{G}=0-253$ dan $\mathrm{B}=$ 9-248), Hijau ( $R=0-255, G=173-255$ dan $B=12-207)$ dan Biru $(\mathrm{R}=3-252, \mathrm{G}$ $=19-255$ dan $\mathrm{B}=250-255)$. Dengan menggunakan threshold tersebut, kita dapat mengklasifikasikan objek sesuai dengan salah satu kriteria threshold di atas. Objek yang tidak masuk salah satu kriteria di atas diklasifikasikan sebagai objek NG.

Ekstraksi bentuk merupakan kelanjutan dari deteksi warna objek. Setelah didapatkan objek warna tertentu, maka dilakukan proses grayscale dan binarisasi pada citra. Proses gray scale didapatkan melalui persaaan (1)

Grayscale $=0.2125 *$ Red $+0.7154 *$ Green + $0.0721 *$ Blue

Ekstraksi bentuk dilakukan pada citra biner dengan menggunakan algoritma shape matching. Dalam algritma shape matching, beberapa ciri objek seperti jumlah pixel, lebar, panjang dan tepian objek dibandingkan dengan objek yang menjadi referensi. Kemiripan objek diukur dengan membandingkan tiap ciri objek sampel dengan ciri objek referensi yang dihitung berdasarkan jarak Euclidian. Jarak Euclidian dihitung untuk tiap titik pada tepian citra sample dan cira referensi. Jarak Euclidian didefinisikan dalam (2)

$$
\text { Jarak Euclidian }=\sqrt{ }\left(x_{1}-x_{2}\right)^{2}+\left(y_{1}-y_{2}\right)^{2}
$$

Dengan $\left(x_{1}, y_{1}\right)$ adalah titik-titik pada tepian citra referensi dan $\left(x_{2}, y_{2}\right)$ adalah titik-titik pada tepian citra sampel.

Dimensi objek diklasifikasi dengan menghitung jumlah pixel dalam objek yang terdeteksi. Pixel objek yang dihitung adalah pixel objek pada citra biner. Dengan mengambil range jumlah pixel yang dikandung oleh setiap objek, maka objek dapat diklasifikasikan dalam tiga kategori dimensi kecil, sedang dan besar. Range jumlah pixel yang digunakan dalam artikel ini ditunjukkan pada Tabel 1. Masing-masing kriteria didapatkan dengan menghitung pixel dari objek citra biner yang terdeteksi pada saat pengkapturan oleh kamera. 
Tabel 1. Klasifikasi objek berdasarkan jumlah pixel

\begin{tabular}{cccc}
\hline Bentuk & $\begin{array}{c}\text { Kecil } \\
\text { (pixel) }\end{array}$ & $\begin{array}{c}\text { Sedang } \\
\text { (pixel) }\end{array}$ & $\begin{array}{c}\text { Besar } \\
\text { (pixel) }\end{array}$ \\
\hline $\begin{array}{c}\text { Lingkaran } \\
\text { Segitiga }\end{array}$ & 82000 & 220000 & 420000 \\
Persegi & 47000 & 120000 & 240000 \\
\hline
\end{tabular}

Dengan menggunakan Tabel 1, kami membuat range jumlah pixel untuk pengklasifikasian objek berdasarkan dimensi dan bentuk yaitu Lingkaran (kecil : 82000 - 220000; sedang: 220000 - 420000; besar: lebih dari 420000), Segitiga (kecil : 47000 - 120000; sedang: 120000 - 240000; besar: lebih dari 240000), dan Lingkaran (kecil : 100000 270000; sedang: 270000 - 540000; besar: lebih dari 540000).

\section{HASIL DAN PEMBAHASAN}

Penelitan ini telah diimplementasikan dalam sebuah konveyor yang didesain mempunyai 10 keluaran . Desain konveyornya ditunjukan dalam Gambar 3. Objek yang diklasifikasi akan melewati konveyor pada sisi kiri, kemudian akan dikapture dan diproses untuk kemudian diklasifikasi sesuai kriteria yang diberikan. Objek yang sesuai dengan kriteria akan keluar pada tiap pintu keluaran sedangkan objek yang $N G$ akan diteruskan ke sisi kanan.

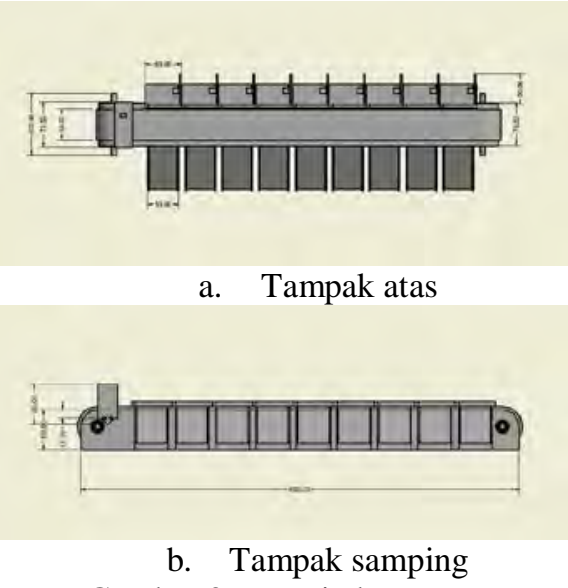

Gambar 3. Desain konveyor

Pengklasifikasian yang dilakukan dalam artikel ini merupakan gabungan dari dua ciri yaitu warna-bentuk, warna-dimensi dan bentuk-dimensi. Objek yang akan diklasifikasi terdiri dari 30 objek yang akan diklasifikasi menjadi 27 klasifikasi dengan kategori baik (GOOD) dan 3 klasifikasi dengan kategori reject (NG). Sampel uji objek kategori baik ditunjukkan pada Gambar 4 sedang untuk kategori $N G$ ditunjukkan pada Gambar 5.

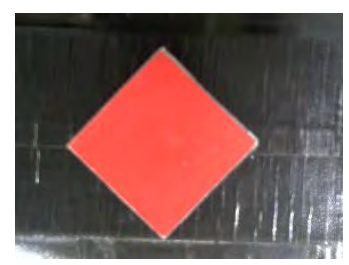

a. Merah-persegi

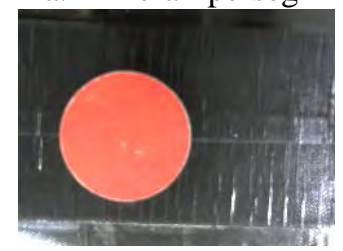

d. Merah-lingkaran



g. Merah-segitiga

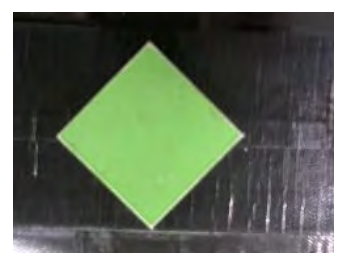

b. Hijau-persegi

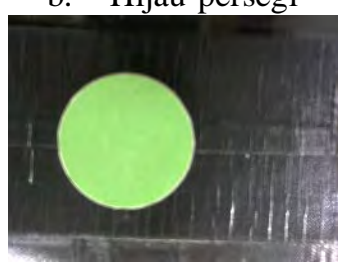

e. Hijau-lingkaran

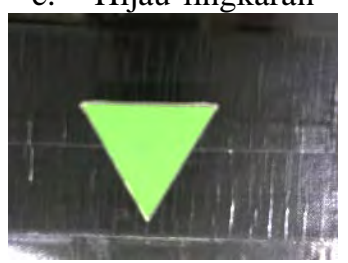

h. Hijau-segitiga

Gambar 4. Data uji kategori baik

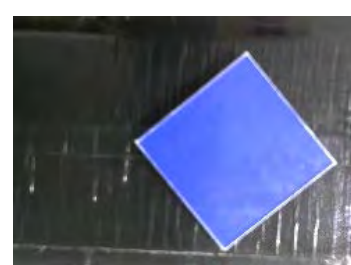

c. Biru-persegi

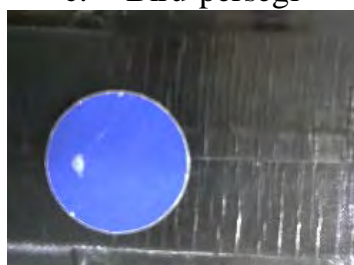

f. Biru-lingkaran

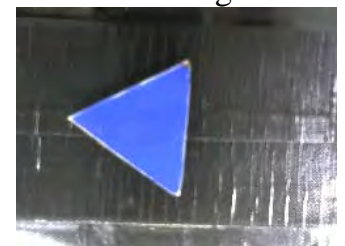

i. Biru-segitiga 



Gambar 5. Data uji kategori NG

Pengujian pertama dilakukan untuk menguji kategori gabungan warna dan bentuk. Pengujian dilakukan 10 kali dengan orientasi dan posisi objek yang berbeda. Hasil pengujian ditunjukkan pada Tabel 2. Kami telah berhasil mengklasifikasikan objek berdasarkan warna dan bentuk menjadi 9 kategori untuk objek yang baik dan 1 kategori NG. Gambar 6-8 menunjukkan Interface hasil klasifikasi untuk kategori warna dan bentuk.

Tabel 2. Hasil Klasifikasi Objek warna dan bentuk

\begin{tabular}{lc}
\hline \multicolumn{1}{c}{ Bentuk - Warna } & $\begin{array}{c}\text { Hasil Klasifikasi } \\
(\%)\end{array}$ \\
\hline Lingkaran - Merah & 100 \\
Lingkaran - Hijau & 100 \\
Lingkaran - Biru & 100 \\
Segitiga - Merah & 100 \\
Segitiga - Hijau & 100 \\
Segitiga - Biru & 100 \\
Persegi - Merah & 100 \\
Persegi - Hijau & 100 \\
Persegi - Biru & 100 \\
NG & 100 \\
\hline
\end{tabular}



Gambar 6. Hasil pengujian objek segitiga berwarna merah

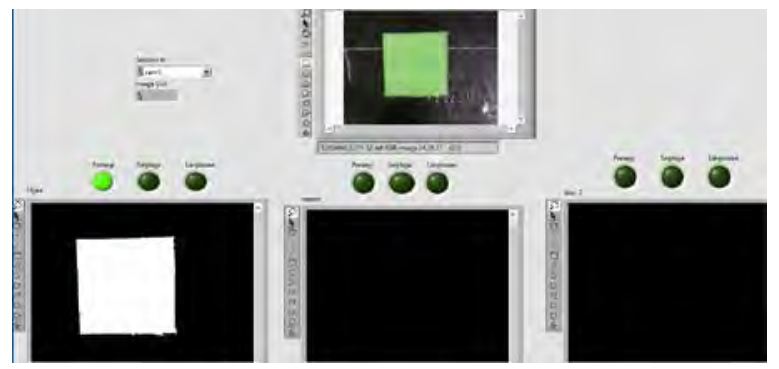

Gambar 7. Hasil pengujian objek persegi berwarna hijau

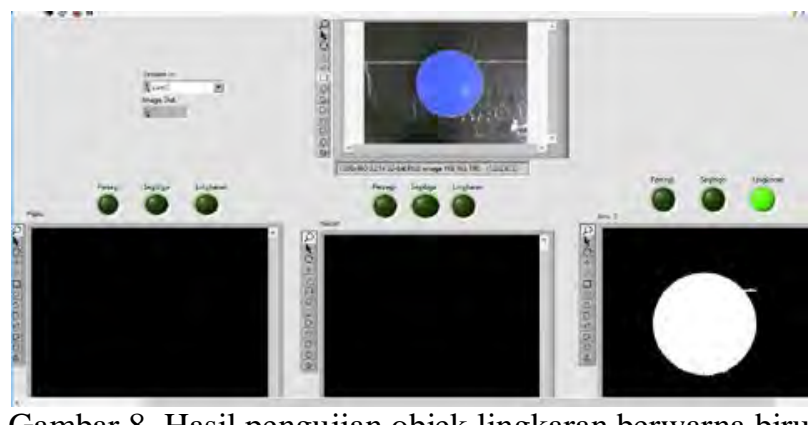

Gambar 8. Hasil pengujian objek lingkaran berwarna biru

Dari pengujian yang sudah dilakukan untuk mengklasifikasi warna dan bentuk, dengan menggunakan filter warna RGB dan range warna pada histrogram RGB, sistem dapat mengklasifikasi objek dengan baik. Pada pendeteksian bentuk, metode Shape Matching dapat mengenali bentuk dengan cepat dan mudah 
menyesuaikan data tamplate referensi yang diberikan. Metode Shape Matching tidak mengharuskan objek pada posisi dan orientasi yang sama, sehingga jika objek dirotasi dan berpindah posisi masih bisa dideteksi dan diklasifikasikan sebagai objek yang sama.

Pengujian kedua dilakukan untuk menguji kategori gabungan warna dan dimensi. Pengujian dilakukan 10 kali dengan posisi objek yang berbeda. Hasil pengujian ditunjukkan pada Tabel 3 . Kami telah berhasil mengklasifikasikan objek berdasarkan warna dan dimensi menjadi 9 kategori untuk objek yang baik dan 1 kategori NG.

Tabel 3. Hasil Klasifikasi objek berdasarkan warna dan dimensi

\begin{tabular}{lc}
\hline \multicolumn{1}{c}{ Warna - Dimensi } & $\begin{array}{c}\text { Hasil Klasifikasi } \\
(\%)\end{array}$ \\
\hline Merah - Kecil & 100 \\
Merah - Sedang & 100 \\
Merah - Besar & 100 \\
Hijau - Kecil & 100 \\
Hijau - Sedang & 100 \\
Hijau - Besar & 100 \\
Biru - Kecil & 100 \\
Biru - Sedang & 100 \\
Biru - Besar & 100 \\
NG & 100 \\
\hline
\end{tabular}

Dimensi objek diperoleh dengan cara membandingkan jumlah pixel citra objek sample dengan citra objek referensi sehingga objek dapat diklasifikasikan sesuai dimensinya kecil, sedang dan besar. Tabel 4 menunjukan hasil pengklasifisikasian objek berdasarkan jumlah pixel.
Tabel 4. Pengklasifikasian objek berdasarkan jumlah pixel

\begin{tabular}{ccc}
\hline Citra & $\begin{array}{c}\text { Jumlah Pixel } \\
\text { yang terdeteksi }\end{array}$ & Klasifikasi \\
\hline & 109444 & Kecil \\
\hline & 279587 & Sedang \\
\hline & 548341 & Besar \\
\hline
\end{tabular}

Pengujian ketiga dilakukan untuk menguji kategori gabungan bentuk dan dimensi. Pengujian dilakukan 10 kali dengan orientasi dan posisi objek yang berbeda. Hasil pengujian ditunjukkan pada Tabel 5. Kami telah berhasil mengklasifikasikan objek berdasarkan warna dan dimensi menjadi 9 kategori untuk objek yang baik dan 1 kategori $N G$. Gambar 9-11 menunjukkan interface hasil klasifikasi untuk kategori bentuk dan dimensi pada objek yang kategori baik. Gambar12 menunjukkan hasil untuk objek kategori $N G$.

Tabel 5. Hasil Klasifikasi objek berdasarkan bentuk dan dimensi

\begin{tabular}{lc}
\hline \multicolumn{1}{c}{ Warna - Dimensi } & $\begin{array}{c}\text { Hasil Klasifikasi } \\
(\%)\end{array}$ \\
\hline Lingkaran - Kecil & 100 \\
Lingkaran - Sedang & 100 \\
Lingkaran - Besar & 100 \\
Persegi - Kecil & 100 \\
Persegi - Sedang & 100 \\
Persegi - Besar & 100 \\
Segitiga - Kecil & 100 \\
Segitiga - Sedang & 100 \\
Segitiga - Besar & 100 \\
NG & 100 \\
\hline
\end{tabular}

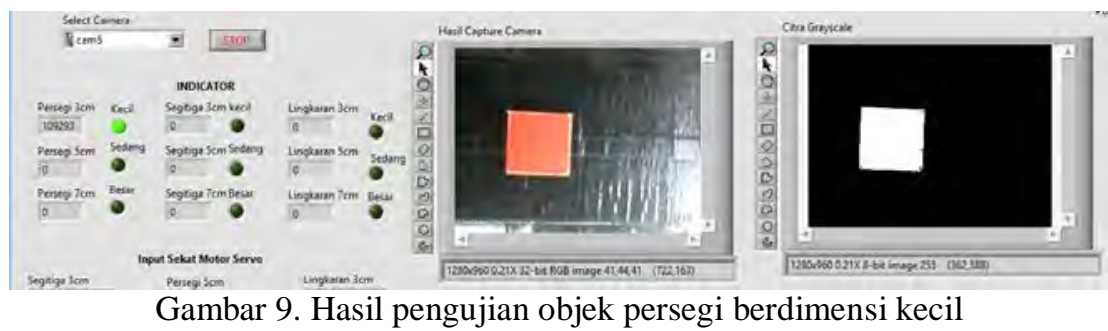




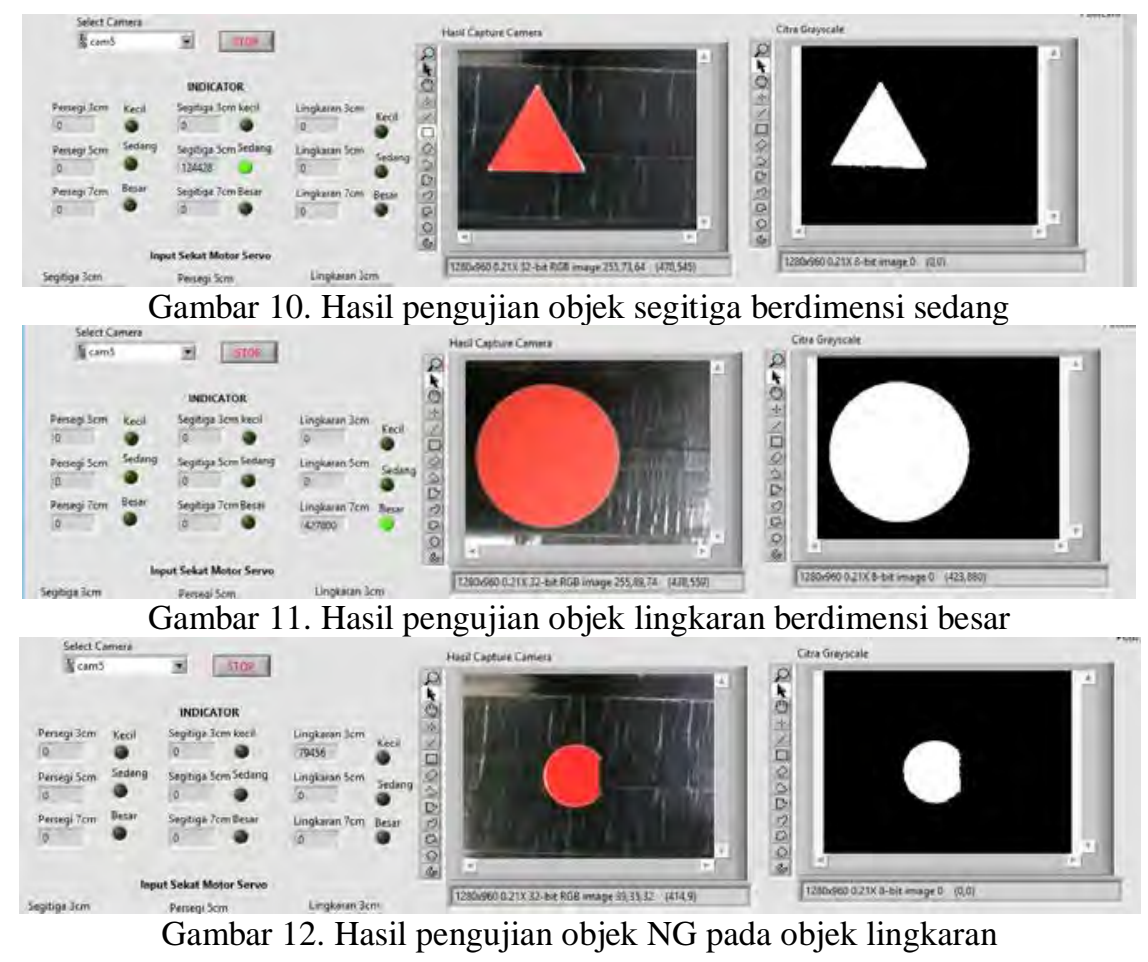

\section{KESIMPULAN}

Artikel ini telah mengembangkan sistem pengklasifikasian objek berdasarkan 3 ciri gabungan bentuk - warna, warna dimensi dan bentuk - dimensi. Sistem yang dibangun telah berhasil mengklasifikasikan objek menjadi 27 kategori untuk objek yang baik dan 3 kategori objek yang reject. Sistem dibangun dalam konveyor yang mempunyai 10 keluaran dengan 9 keluaran untuk kategori baik dan 1 kategori reject. Sembilan objek dengan kategori yang baik telah berhasil dipilah oleh mesin konveyor ke keluaran yang dituju dan kategori reject diteruskan ke keluaran reject. Keakuratan klasifikasi untuk masing-masing kategori adalah $100 \%$ dari 10 pengujian dengan mengubah posisi dan orientasi objek.

Untuk hasil yang lebih baik, perlu dicoba untuk mengubah dimensi, warna maupun bentuk objek dengan perbedaan yang cukup ekstrim seperti berbeda dimensi $1 \mathrm{~mm}$, berbeda intensitas warna dan bentuk yang sedikit berbeda. Sehingga keakuratan sistem akan teruji dengan lebih baik. Selain itu, perlu dicoba juga metoda lain seperti filter warna HSV maupun YCbCr untuk mendeteksi warna objek.

\section{DAFTAR PUSTAKA}

[1] Arbye, S. \& Setiyono, B. (2014). Pengendalian pada Prototipe Konveyor Pemisah Barang Berdasarkan Warna Menggunakan Sensor DT-Sense Color dengan Controller ATMEGA 1 dan PLC Omron CPM1-A. Transmisi, 16, 8691.

[2] Chirysev, Y., Kruglov, A., Atamanova, A. \& Zavada, S. (2017) Detection and Dimension of Moving Objects using Single Camera Applied to the Round Timber Measurement. Proc. of Federated Conf. on Computer Science and Information, 49-56.

[3] Chitra, D., Manigandan, T. \& Devarajan, N. (2009). Shape Matching and Object Recognition Using Dissimilarity Measures with Hungarian Algorithm. Proc. of The Intl. Conf. on Man-Machine System, 6 pages. 
[4] Garad, P. V. (2017). Object Sorting Robot Based On the Shape. Intl. Journal of Advance Research, Idea and Innovations In Technology, 3, 129-134.

[5] Gode, C. \& Atish, K. (2016). Object Detection using Color Clue and Shape Feature. Intl. Conf. on Wireless Communication, Signal Processing and Networking.

[6] Hani, A. K. \& Mustafah, M. (2013). Color-based Object Detection and Tracking for Autonomous Quadrotor UAV. Proc. of Intl. Conf. on Mechatronics.

[7] Hutabarat, R., Sulistiyanti, S. \& Nasrullah, E. (2013). Rancang Bangun Konveyor Penyortiran Barang dengan Pengenalan Pola Bentuk dan Warna Menggunakan Webcam. Jurnal Rekayasa dan Teknik Elektro, 7, 73-77.

[8] Kim, Y., Kim, A. \& Jeoung, H. (2014). RGB Color Based the Fire Detection Algorithm in Video Sequence on Wireless Sensor Network. Intl. Journal of Distributed Sensor Network, 10.

[9] Kondhare, A., Singh, G., Hiralkar, N. \& Vanjale, M. (2014). Colour and Shape Based Object Sorting. Intl. Journal of Scientific Research and Education, 2, 553-562.

[10] Mane, S. \& Yangandul, C. (2016). Calculating the Dimensions of an Object using Single Camera by Learning the Environment. Intl. Conf. on Applied an Theoretical Computing and Communication Technology.

[11] Rahman, M., Purnama, I. K. \& Purnomo, M. H. (2014).Simple Method of Human Skin Detection using HSV and YCbCr Color Spaces. Intl. Conf. on Intelligent Autonomous Agents, Networks and Systems.
[12] Sagita, H. \& Rozany, B. A. (2017). Model Sistem Automasi Sortir Barang Berdasarkan Warna Menggunakan Programmable Logic Control Berbasis Mikrokontroler. Jurnal Teknik Informatika dan Sistem Informasi, 6, 1367-1374.

[13] Pangestu, A. P., Ramdhani, M. \& Nugraha, R. (2016). Perancangan dan Implementasi Sistem Kendali Lengan Robot Penyortir Barang Berdasarkan Warna. Proc. of Engineering, 40744081.

[14] Toshev, A., Taskar, B. \& Daniilidis, K. (2012). Shape-Based Object Detection via Boundary Structure Segmentation. Intl. Journal of Computer Vision, 99, 123-146. 
Budi Sugandi, dkk. Klasifikasi Objek Berdasarkan... 